https://doi.org/10.48009/2_iis_2009_175-184

\title{
DESIGNING AN ASSESSMENT TOOL FOR MEASURING E-READINESS OF IRANIAN ICT COMPANIES
}

\author{
Ali Nabavi, Allameh Tabataba'i University, Iran, alinaba@yahoo.com \\ Reggie Davidrajuh, University of Stavanger, Norway, reggie.davidrajuh@uis.no
}

\begin{abstract}
This paper proposes an e-readiness assessment model for evaluating the e-readiness of ICT Companies of Iran. The proposed e-readiness model consists of dimensions and indicators which are selected by a multilateral survey of existing frameworks and models of nations and SMEs in ereadiness assessment area. The results of this research show that the two dimensions, networked applications and services, are at a low level among the Iranian ICT companies whereas electronic infrastructure dimension is at the highest level.
\end{abstract}

Keywords: Information and Communication Technology (ICT), E-readiness, digital divide, Iranian ICT companies

\section{INTRODUCTION}

Measuring the access and use of ICT is called ereadiness which is the status or quality of readiness for a society or an economy to use electronic technology (Bridges, 2005a). High level of ereadiness allows enterprises to transact business electronically in order to achieve less turn-around time, faster delivery of services, enhanced product choices, etc. (Mutula \& Brakel, 2006).

Due to its importance, e-readiness assessments of businesses are studied by various individuals and organizations using a number of indices and models (Bridges, 2005b). The Most important organizations who are working in this field are those of Economic Co-operation and Development (OECD), World Information Technology and Services Alliance (WITSA) and Asian Pacific Economic Corporation (APEC) (OCED \& WITSA, 1999; APEC, 2000).

In this research, e-readiness assessment models of the nations and small and medium-sized enterprises (SMEs) are surveyed in order to make a holistic model for e-readiness assessment of ICT Companies. Then, the proposed model is applied for e-readiness measure of three ICT Companies in Iran.

\section{LITERATURE REVIEW}

The e-readiness concept was invented to provide a unified framework to evaluate the breadth and depth of the digital divide between more and less developed or developing countries in the late 1990s. The first efforts in defining e-readiness were undertaken in 1998 by the Computer Systems Policy Project (CSPP) when it developed the first e-readiness assessment tool known as Readiness Guide for Living in the Networked World. CSPP defined ereadiness with respect to a community that had highspeed access in a competitive market; with constant access and application of ICTs in schools, government offices, businesses, healthcare facilities and homes; user privacy and online security; and government policies which are favorable to promoting connectedness and use of the network (Bridges.org, 2001). With the development of the first e-readiness tool, several e-readiness tools have been emerged by development agencies, research organizations, universities, business enterprises and individuals.

\section{Tools for Measuring E-Readiness}

Some pioneer organizations in developing ereadiness assessment tools are: McConnell International (MI), a global technology, policy and management consulting firm (with its Ready? Net.Go tool), International Development centre at Harvard University (with its Network Readiness Index tool), Economist Intelligent Unit (with its e-readiness Rankings), the United Nations Conference on Trade and Development (UNCTAD)(with its ICT Development Index), Mosaic Group (with a Framework to assess Diffusion of the Internet ) (Rizk, 2004).

Largely, all the e-readiness tools measure the ereadiness phenomena at national level across key sectors of the economy and in general each of the tools uses a different definition of e-readiness and techniques of its measurement (Bridges.org, 2001). Docktor (2002) alluding to these variations observed that the diversity of e-readiness definitions represented the multiple levels of ICT development and the exact definition of what constituted 'ereadiness' was still open for debate. 
E-readiness assessment models measure various areas like e-government, e-business, e-learning and etc. Consequently, due to this research's concentration on E-readiness assessment for ICT companies, Literature review of e-business assessment tools has been mentioned.

The World Information Technology and Services Alliance research (WITSA) (1999) focused on the direct experiences of companies with e-commerce and their subjective views of what is needed to promote e-commerce. The questions cover a range of issues, including: barriers to technology industry, role of consumer trust, problems with e-commerce technology, internal business practices that support ecommerce, workforce problems, taxes, public policy issues, and resistance from consumers (WITSA, 1999).

Barua et al., (1999) proposed an assessment method for measuring the Internet Economy. The Internet Economy Indicators seek to provide a foundation for conceptualizing and measuring the various components of the Internet Economy. These indicators - the Internet Economy Revenues Indicator and the Internet Economy Jobs Indicator are built on an analysis of four layers of the Internet Economy. The Internet Economy Indicators divide the Internet Economy into four distinct but related layers: Internet infrastructure, Internet applications, Internet intermediaries and Internet-based transactions (Barua et al., 1999).

Asian Pacific Economic Corporation (APEC) (2000) define readiness as the degree to which an economy or community is prepared to participate in the digital economy. Readiness is assessed by APEC by determining the relative standing of the economy in the areas that are most critical for e-commerce participation.

\section{RESEARCH METHODOLOGY}

\section{Initial Design of the Questionnaire}

From the literature study of numerous tools for measuring e-readiness of businesses, a preliminary questionnaire was designed that consists of five dimensions for rating e-readiness of ICT companies in Iran. The five dimensions posses a number of indicators (figure-1):

1. Basic infrastructure and technology (20 indicators)

2. Access to network applications and services (14 indicators)
3. Promotion and facilitation in the ICT sector and trade in ICT goods (10 indicators)

4. Human resources and Skills (9 indicators)

5. Positioning for the digital economy through healthy business environment to conduct ebusiness ("networked world enablers") indicators)

The initial questionnaire was sent to 25 managers of ICT companies listed in the mailing list of the High Council of Informatics (HCI). HCI is the coordinating office for ICT companies operating in the Iranian market. Currently, there are 2073 ICT companies listed in the HCI mailing list. HCI also evaluates and ranks the ICT companies; there are 6 levels of ranks: from 1 (weak) to 6 (strong).

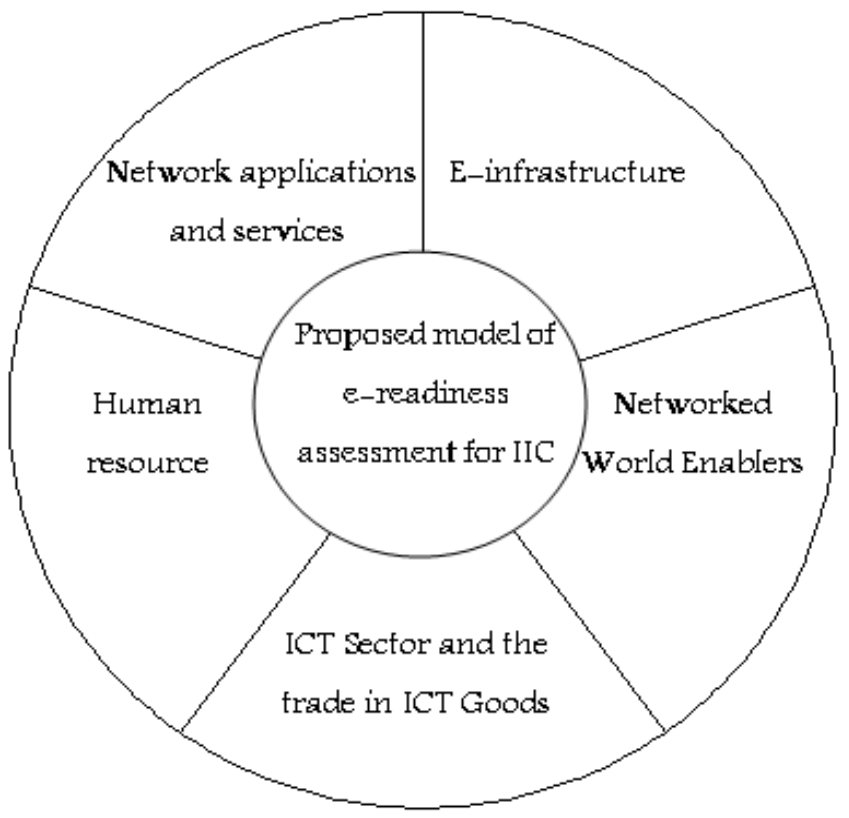

Figure-1: The five dimensions of the tool

The initial questionnaire was sent to 25 companies that were randomly selected from the HCI list. The recipients (managers of the companies) were asked to comment on the format, quality and importance of the dimensions and the indicators of the initial questionnaire. There were 10 respondents. Using the feedback from the respondents, the questionnaire was revised. Additionally, 5 renowned experts were selected from the companies that were awarded "the Bests of the year" by the HCI; these experts have a expertise of ICT and e-readiness, due to their educational qualification and working experience. These experts were also evaluated and improved the composition of the questionnaire.

\section{Data Collection}


The revised questionnaire was used to examine three ICT Companies that had received three different levels of HCI ranking (strong, medium and weak).

\section{RESULTS AND IMPLICATIONS}

Figure-2 shown below summarizes the e-readiness measures of three ICT companies in Iran. Tables 1-6 shows responds from three ICT Companies that had received three different levels of HCI ranking; in tables 1-6, company-one is ranked strong, companytwo is ranked medium and company-three is ranked weak.

The aim of this study is to design an e-readiness model for measuring e-readiness ICT companies in Iran and also to measure e-readiness of some of the companies. This research started with surveying the E-readiness assessment models of nations and small and medium-sized enterprises (SMEs) and then making a preliminary model. The model was revised based on the feedback from industry and due to experts' comments. Then, this model was used to examine e-readiness of three companies that are ranked at different levels; the results are as follows:

- Tables 1-6 reveal that there is a strong correlation between $\mathrm{HCI}$ ranking and e-readiness values obtained from the three companies; In overall measures, company-one, which is ranked as a strong company, scored 3.5 out of 5.0. Company-two, a medium ranked company, scored 2.4, and company-three, a company ranked as a weak company, scored 1.9. Similar differences are seen in other tables too, in measuring e-readiness scores based on dimensions.

- These three companies perform well on the "human resources" dimensions. This is obvious, as Iran has a vast pool of highly skilled workers.

- The companies also perform well on the "Einfrastructure" dimension. Perhaps, this is due to the fact that cost of ownership of technologies are becoming cheaper and enable painless penetration of ICT into companies of varying sizes and levels. Another reason for this phenomenon is perhaps increasing foreign investments in Iranian ICT sector.

- The company that rankled as strong had a high score on the "Networked enablers" (general business environment to conduct e-business), whereas the other two companies scored poorly. This can argued as though there is lack of public awareness and business policies and practices to conduct e-business in Iran, the strong companies are quick to adapt to the situation. Whereas,

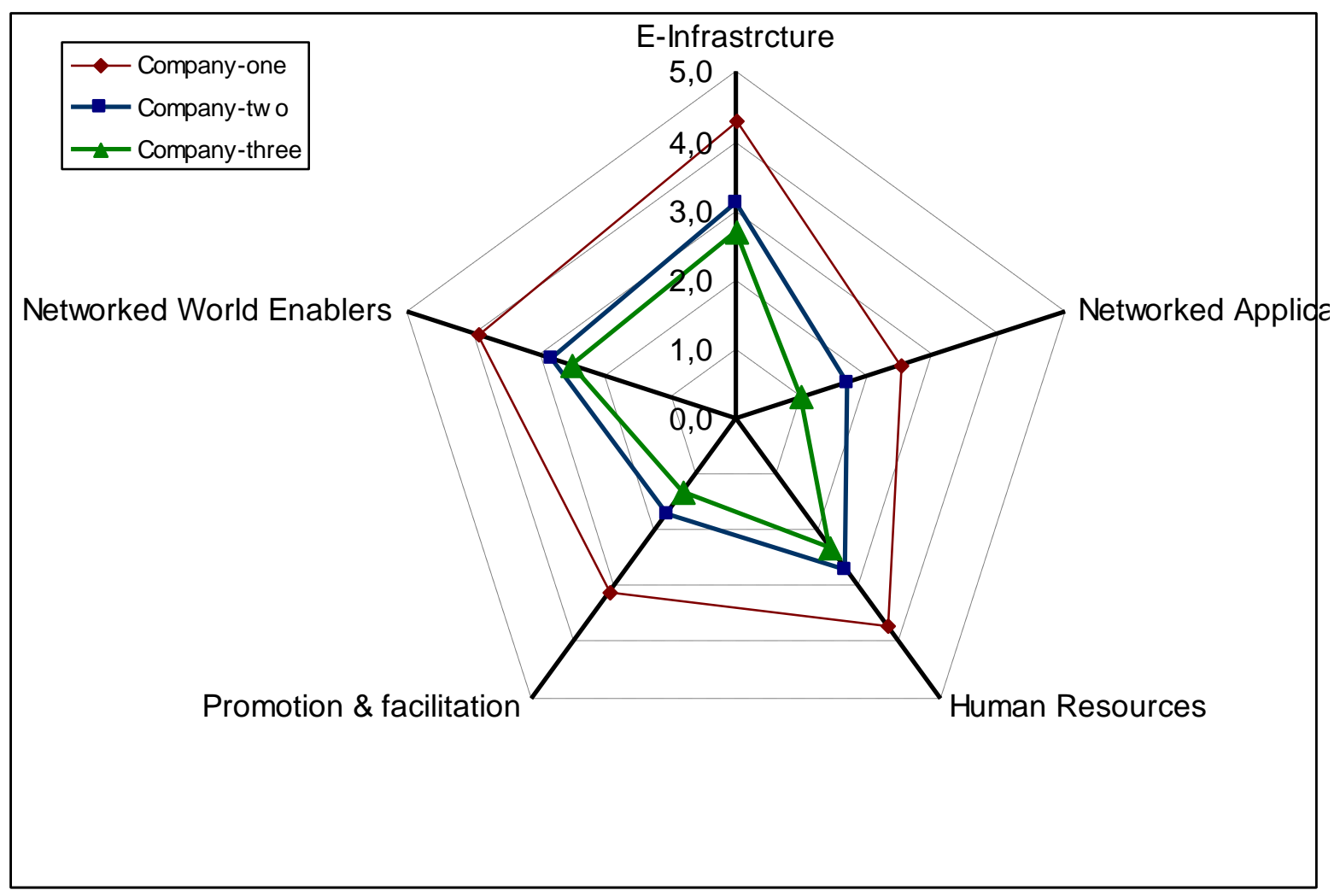


weaker companies struggle to survive in the insecure environment.

- On the "Network Applications and Services" dimension, all three companies scored poorly. This simply means, as opposed to Western world, ICT companies in Iran are yet to offer high quality and competitive services, with the use of ICT.

Limitations of the study and future research:

This study only examined three ICT companies. Thus, it will be difficult to generalize the results for a general Iranian ICT companies.

\section{REFERENCES}

1. Asian Pacific Economic Corporation (APEC). (2000), "e-commerce readiness assessment guide". Auckland: APEC[Online]. Available at: http://www.schoolnetafrica.net/fileadmin /resources/APEC E-

2. Barua, A., Pinnell, J., Shutter, J. \& Whinston, A. B. (1999), "Measuring the Internet Economy: An Exploratory Study ", Center for Research in Electronic Commerce, Graduate School of Business, The University of Texas at Austin[Online]. Available at: http://cism.bus.utexas.edu/works/articles/internet _economy.pdf [Accessed 16 July 2006].

3. Bojadziev, G. \& Bojadziev, M. (2000), "Fuzzy Logic for Business, Finance, and Management", World Scientific Publishing Co.

4. Bridges.Org. (2001), "Comparison of e-readiness assessment models", [Online]. Available at: http://www.bridges.org/eredainess/tools.html [Accessed 18 July 2004].

5. Bridges. (2005a), "E-Ready for What? EReadiness in Developing Countries: Current Status and Prospects toward the Millennium Development Goals", Cape Town.

6. Bridges. (2005b), "E-readiness Assessment Tools Comparison", Cape Town.

7. Center for International Development and Conflict Management(CIDCM) at the University of Maryland. (1998), "Negotiating the Net Model".

8. Choucri, N., Maugis, V., Madnick, S., Siegel, M., Gillet, S., O’Donnel, M., et al. (2003), "Ereadiness for what? ",Cambridge: MIT [Online].
Available

at

http://ebusiness.mit.edu/research/papers/177_Ch oucri_GLOBAL_eREADINESS.pdf [Accessed 26 August 2006].

9. City of Seattle Department of Information Technology \& the Citizens Telecommunications and Technology Advisory Board. (2000), "Information technology indicators for a healthy community" [Online]. Available at: http://www.cityofseattle.net/tech/indicators[Acce ssed 25 October 2006].

10. Commonwealth of Australia. (2000), "The National Office for the Information Economy", Ecommerce across Australia.

11. Computer Systems Policy Project. (1998), "Readiness Guide for Living in the Networked World" [Online]. Available at: http://www.cspp.org/projects/readiness/ [Accessed 26 August 2006].

12. Department of Information Technology (DIT). (2004), "INDIA: E-Readiness Assessment Report". Available http://www.mit.gov.in/ereadiness/report.asp [Accessed 26 August 2006].

13. Docktor, R. (2002). "E-readiness in 2002: Defining and achieving your e-fitness goals" [Online]. Available at: http://www.ip3.org/pub/docktor.htm [Accessed 26 August 2005].

14. Economist Intelligence Unit (2006), "E-readiness rankings", London, New York, Hong Kong. Available http://www.eiu.com

15. European Commission. (2000), "List of eEurope Benchmarking indicators", Bruxelles.

16. European Commission. (2005), "A Guide to ICT Usage Indicators", Bruxelles.

17. http://www.moneymattersinstitute.org

18. International Telecommunication Union (2003), "Telecommunication Indicators Handbook", Geneva.

19. Jutla D., et al. (2002), "Government Support for the E-Readiness of Small and Medium Sized Enterprises".

20. Maksoud, S. S. \& Yousef, M. A. A. (2003), "Information and communication technology for small and medium enterprise in Egypt", Cairo: SME Development Unit-Ministry of Foreign Trade, 1-15. 
21. Mutula, S.M. \& Brakel, P.V.. (2006), "An evaluation of e-readiness assessment tools with respect to information access: Towards an integrated information rich tool", International Journal of Information Management, 26, 212223.

22. Organization for Economic Co-operation and Development, (OCED). (1999), "Defining and measuring e-commerce: a status report", Working Party on Indicators for the Information Society, Paris. Available http://www.oecd.org

23. Organization for Economic Co-operation and Development. (2001), "Measuring ICT usage and electronic commerce in enterprises: proposal for a model questionnaire", Working Party on Indicators for the Information Society, Paris. Available http://www.oecd.org

24. Organization for Economic Co-operation and Development. (2002), "Measuring the Information Economy". Available http://www.oecd.org

25. Organization for Economic Co-operation and Development. (2005), "Guide to Measuring the Information Society", Paris. Available http://www.oecd.org

26. Pankaj, J. (2003), "E-Readiness Assessment for SMEs in India", India.

27. Pennoni, F., Tarantola, S.\& Latvala, A. (2005), "The 2005 European e-Business Readiness Index".

28. Ramayah, T. et al. (2001), "SME EREADINESS: IS IT UNIDIMENSIONAL OR MULTIDIMENSIONAL? ",Malaysia.

29. Rizk, N. (2004), "E-readiness assessment of small and medium enterprises in Egypt: A micro study". Cairo: American University [Online]. Available at: http://www.sba.luc.edu/orgs/meea/volume6/Rizk .htm

30. Yin, Robert K. (2003), "Case Study Research: Design and Methods", Third Edition, Applied Social Research Methods Series, Vol 5 .

31. Rubin, H. A. and MetricNet.com. (2002), "The 2002 Global Technology Index".

32. Saaty, L. (1990), "Decision Making for leaders", RWS publications.

33. Statistical Indicators Benchmarking the Information Society (SIBIS). (2003), "New eEurope Indicator Handbook", Bruxelles.
34. Statistics Norway January. (2001), "Use of ICT in Nordic enterprises".

35. Swedish International Development Cooperation Agency. (2001), "A Three-Country ICT Survey for Rwanda, Tanzania and Mozambique", Stockholm.

36. The European e-Business Market Watch European Commission Enterprise \& Industry Directorate General. (2005), "The European eBusiness Report".

37. The World Information Technology and Services Alliance (WITSA). (1999), "International Survey of Electronic Commerce", London.

38. United Nations. (2005a), "core ICT indicators", Partnership on Measuring ICT for Development, New York.

39. United Nations. (2005b), "Information Society Indicators", New York.

40. United Nations Conference on Trade and Development (UNCTAD). (2003), "Information and communication technology (ICT) development indices", New York.

41. United Nations Development Programme (UNDP). (2001), "ICT and Human Development: Towards Building a Composite Index for Asia", New York.

42. United Nations Educational, Scientific and Cultural Organization (UNESCO). (2004), "Performance Indicators on ICT Use in Education project", New York.

43. United Nations Economic Commission for Europe. (2002), "Country Readiness Assessment Report: Concept, Outline, Benchmarking and Indicator".

44. United State Association for International Development (UASID). (2000), "Republic of Armenia: ICT Assessment".

45. Walliman, N. (2001), "Your research project", 1st London, SAGE Publications.

46. World Bank. (2001a), "World Development Indicators", Washington.

47. World Bank, The Knowledge Assessment Methodology and Scorecards. (2001b), "Knowledge for Development Program".

48. World Bank. (2004), "Knowledge economy index (KEI) ".

49. World Bank. , "Korea: SME e-readiness questionnaire". Available at: http://info.worldbank.org/etools/docs/library/864 
48/ses1.2_koreasme_ereadiness.pdf [Accessed 28 August 2005].

50. World Economic Forum. (2001-2002), "The Networked Readiness Index: Measuring the Preparedness of Nations for the Networked World".
51. Zhu, K., Kraemer, K.L. \& S, Xu. (2003), "Ebusiness adoption by European firms: A crosscountry assessment of the facilitators and inhibitors", European Journal of Information Systems, 12(4), 251-268.

\begin{tabular}{|c|c|c|c|c|c|c|c|c|c|c|}
\hline & & 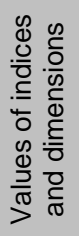 & 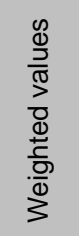 & 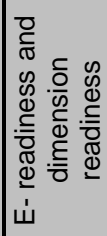 & 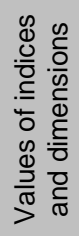 & 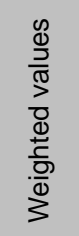 & 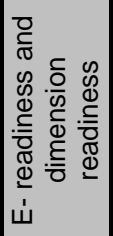 & 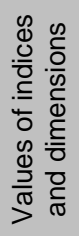 & 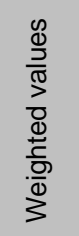 & 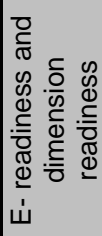 \\
\hline & & \multicolumn{3}{|c|}{ Company-one } & \multicolumn{3}{|c|}{ Company-two } & \multicolumn{3}{|c|}{ Company-three } \\
\hline \multirow{5}{*}{ 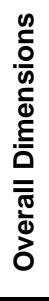 } & E-infrastructure & 4.279 & 0.86 & \multirow{5}{*}{3.543} & 3.139 & 0.631 & \multirow{5}{*}{2.415} & 2.72 & 0.546 & \multirow{5}{*}{1.981} \\
\hline & Network applications and services & 2.516 & 0.464 & & 1.668 & 0.308 & & 1.043 & 0.192 & \\
\hline & Human resource & 3.765 & 0.777 & & 2.671 & 0.551 & & 2.281 & 0.47 & \\
\hline & $\begin{array}{l}\text { ICT Sector and the trade in ICT } \\
\text { Goods }\end{array}$ & 3.13 & 0.61 & & 1.701 & 0.331 & & 1.263 & 0.246 & \\
\hline & Networked World Enablers & 3.901 & 0.833 & & 2.783 & 0.594 & & 2.46 & 0.525 & \\
\hline
\end{tabular}

Table-1: Overall e-readiness values of three ICT companies 


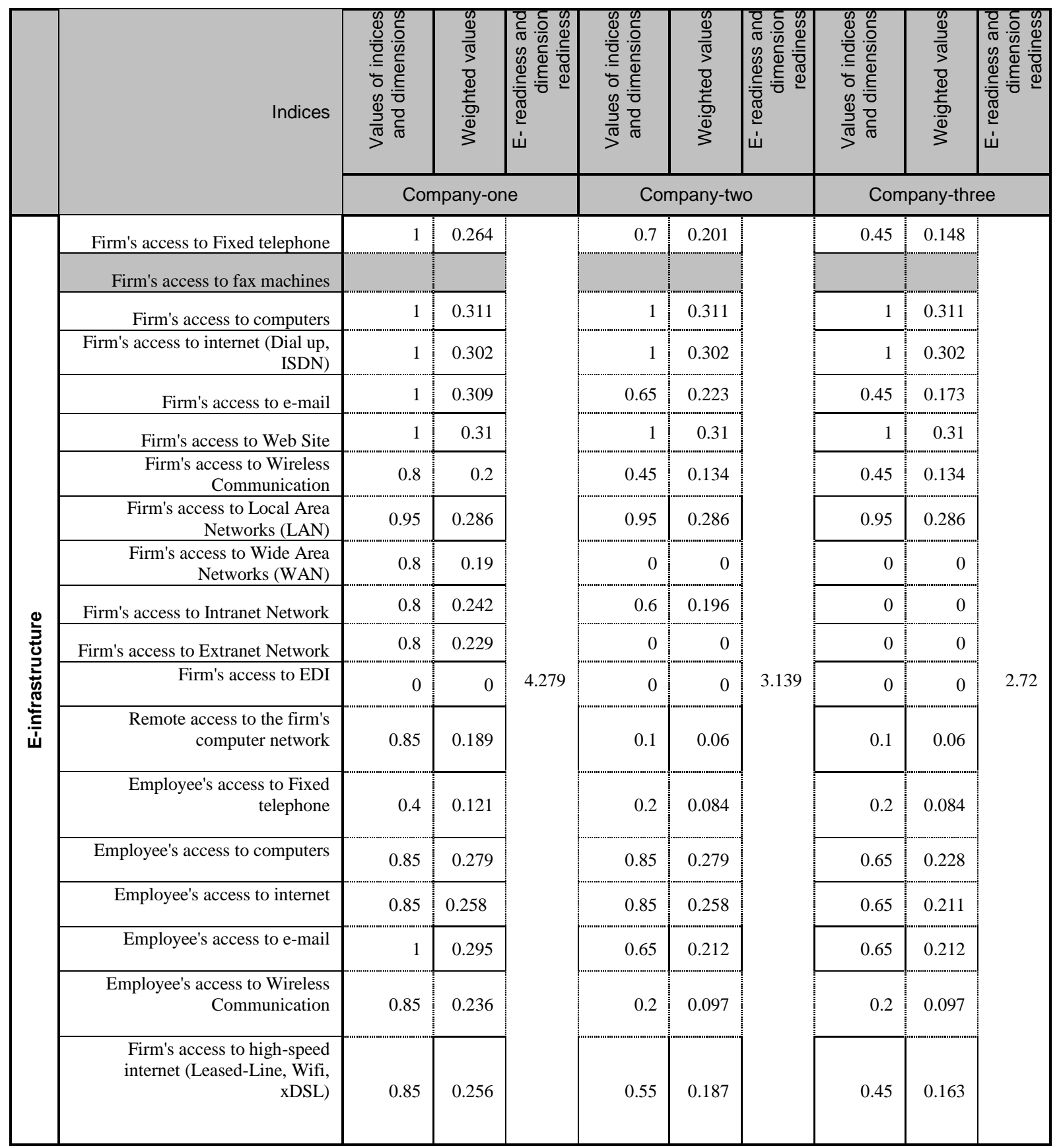

Table-2: E-readiness values of three ICT companies based on deminesion-1: e-infrastructure 


\begin{tabular}{|c|c|c|c|c|c|c|c|c|c|c|}
\hline & Indices & 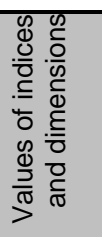 & $\begin{array}{l}0 \\
0 \\
\frac{0}{3} \\
\frac{0}{0} \\
0 \\
0 \\
\frac{0}{ \pm} \\
\frac{0}{0} \\
\frac{0}{3}\end{array}$ & 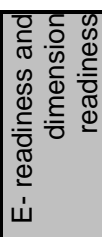 & 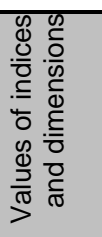 & 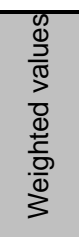 & 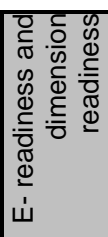 & 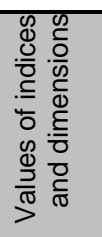 & 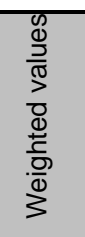 & 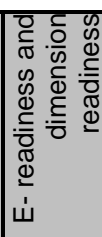 \\
\hline & & \multicolumn{3}{|c|}{ Company-one } & \multicolumn{3}{|c|}{ Company-two } & \multicolumn{3}{|c|}{ Company-three } \\
\hline \multirow{13}{*}{ 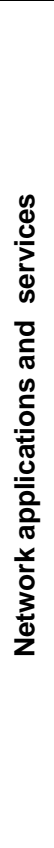 } & $\begin{array}{r}\text { Firm's use of Supply Chain } \\
\text { management }\end{array}$ & 0.6 & 0.291 & \multirow{13}{*}{2.516} & 0.4 & 0.223 & \multirow{13}{*}{1.668} & 0 & 0 & \multirow{13}{*}{1.043} \\
\hline & $\begin{array}{r}\text { Firm's use of Customer } \\
\text { Relationship management }\end{array}$ & 0.6 & 0.285 & & 0.45 & 0.235 & & 0.45 & 0.235 & \\
\hline & $\begin{array}{r}\text { Firm's use of Enterprise Resource } \\
\text { Planning }\end{array}$ & 0 & 0 & & 0 & 0 & & 0 & 0 & \\
\hline & Firm's use of E-Purchase & 0 & 0 & & 0 & 0 & & 0 & 0 & \\
\hline & Firm's use of E-Sale & 0 & 0 & & 0 & 0 & & 0 & 0 & \\
\hline & $\begin{array}{r}\text { Firm's use of Information } \\
\text { Systems }\end{array}$ & 1 & 0.444 & & 1 & 0.444 & & 0.45 & 0.248 & \\
\hline & $\begin{array}{r}\text { Firm's use of Website } \\
\text { maintenance containing } \\
\text { management systems }\end{array}$ & 0.85 & 0.338 & & 0.85 & 0.338 & & 0.8 & 0.322 & \\
\hline & Firm's use of E-Payment & 0 & 0 & & 0 & 0 & & 0 & 0 & \\
\hline & $\begin{array}{r}\begin{array}{r}\text { Firm's use of e-exchange of } \\
\text { documents }\end{array} \\
\end{array}$ & 0.55 & 0.271 & & 0.45 & 0.238 & & 0.45 & 0.238 & \\
\hline & Firm's use of E-Marketing & 0.65 & 0.307 & & 0 & 0 & & 0 & 0 & \\
\hline & Firm's use of E-Business & 0.65 & 0.325 & & 0 & 0 & & 0 & 0 & \\
\hline & \multicolumn{3}{|l|}{ Information search } & & & & & & & \\
\hline & $\begin{array}{r}\text { Firm's use of knowledge } \\
\text { management applications }\end{array}$ & 0.55 & 0.256 & & 0.35 & 0.192 & & 0 & 0 & \\
\hline
\end{tabular}

Table-3: E-readiness values of three ICT companies based on deminesion-2: network applications 


\begin{tabular}{|c|c|c|c|c|c|c|c|c|c|c|}
\hline & Indices & 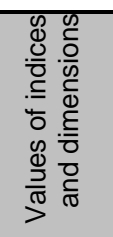 & $\begin{array}{l}\text { क } \\
\text { D } \\
\frac{3}{0} \\
3 \\
0 \\
\frac{0}{0} \\
\frac{1}{5} \\
\frac{0}{0} \\
3\end{array}$ & 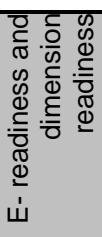 & 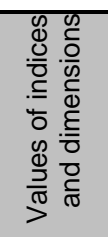 & $\begin{array}{l}0 \\
0 \\
\frac{0}{2} \\
\frac{1}{10} \\
0 \\
0 \\
\frac{0}{1} \\
\frac{0}{0} \\
\frac{0}{10} \\
3\end{array}$ & 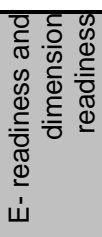 & 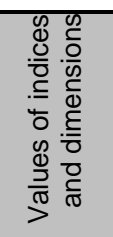 & $\begin{array}{l}0 \\
0 \\
\frac{0}{1} \\
\frac{10}{3} \\
0 \\
0 \\
\frac{0}{5} \\
\frac{0}{0} \\
3\end{array}$ & 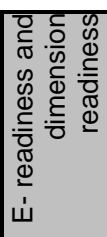 \\
\hline & & \multicolumn{3}{|c|}{ Company-one } & \multicolumn{3}{|c|}{ Company-two } & \multicolumn{3}{|c|}{ Company-three } \\
\hline \multirow{8}{*}{ 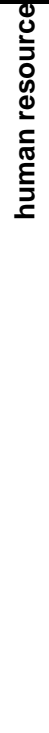 } & IT skilled workers in firm & High & 0.517 & \multirow{8}{*}{3.765} & High & 0.517 & \multirow{8}{*}{2.671} & Medium & 0.387 & \multirow{8}{*}{2.281} \\
\hline & IT skilled consultants in firm & High & 0.487 & & Medium & 0.365 & & Medium & 0.365 & \\
\hline & $\begin{array}{r}\text { Number of IT workers with } \\
\text { relevant educations }\end{array}$ & Medium & 0.296 & & Low & 0.197 & & Low & 0.197 & \\
\hline & $\begin{array}{r}\text { Number of employees familiar } \\
\text { with IT concepts, usages and } \\
\text { advantages }\end{array}$ & High & 0.485 & & Medium & 0.364 & & Medium & 0.364 & \\
\hline & $\begin{array}{r}\text { Number of managers familiar } \\
\text { with IT concepts, usages and } \\
\text { advantages }\end{array}$ & High & 0.572 & & High & 0.572 & & High & 0.572 & \\
\hline & Duration of IT training & Medium & 0.382 & & Low & 0.254 & & $\begin{array}{l}\text { very } \\
\text { Low }\end{array}$ & 0.127 & \\
\hline & $\begin{array}{r}\text { Number of workers familiar with } \\
\text { English language as a business } \\
\text { prerequisite }\end{array}$ & Medium & 0.402 & & Medium & 0.402 & & Low & 0.268 & \\
\hline & $\begin{array}{r}\text { Human resource software } \\
\text { applications }\end{array}$ & $\begin{array}{l}\text { very } \\
\text { High }\end{array}$ & 0.625 & & not exist & 0 & & not exist & 0 & \\
\hline
\end{tabular}

Table-4: E-readiness values of three ICT companies based on deminesion-3: human resources

\begin{tabular}{|c|c|c|c|c|c|c|c|c|c|c|}
\hline & Indices & 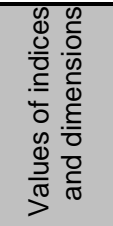 & $\begin{array}{l}0 \\
0 \\
\frac{0}{0} \\
\frac{10}{3} \\
0 \\
\frac{0}{7} \\
\frac{0}{0} \\
\frac{0}{3}\end{array}$ & 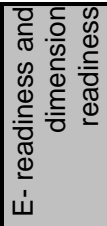 & 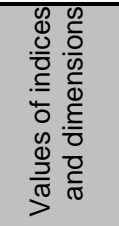 & $\begin{array}{l}0 \\
0 \\
\frac{1}{10} \\
\frac{10}{3} \\
0 \\
\frac{0}{ \pm} \\
\frac{0}{10} \\
3\end{array}$ & 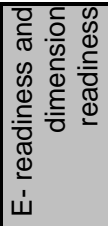 & 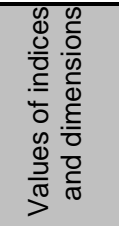 & $\begin{array}{l}\frac{0}{0} \\
\frac{0}{10} \\
\frac{10}{3} \\
\frac{0}{0} \\
\frac{d}{ \pm} \\
\frac{0}{01} \\
3\end{array}$ & 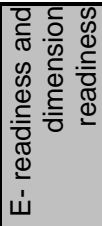 \\
\hline & & \multicolumn{3}{|c|}{ Company-one } & \multicolumn{3}{|c|}{ Company-two } & \multicolumn{3}{|c|}{ Company-three } \\
\hline \multirow{3}{*}{ 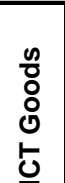 } & $\begin{array}{r}\text { Free partnership of foreign } \\
\text { investors in e-business }\end{array}$ & Low & 0.306 & \multirow{9}{*}{3.13} & $\begin{array}{l}\text { very } \\
\text { Low }\end{array}$ & 0.154 & \multirow{9}{*}{1.701} & $\begin{array}{l}\text { very } \\
\text { Low }\end{array}$ & 0 & \multirow{9}{*}{1.263} \\
\hline & $\begin{array}{r}\text { Average income from ICT as a } \\
\text { percentage of GDP }\end{array}$ & Low & 0.287 & & Low & 0.288 & & Low & 0.288 & \\
\hline & ICT manufactured exports & Medium & 0.421 & & $\begin{array}{l}\text { very } \\
\text { Low }\end{array}$ & 0.141 & & $\begin{array}{l}\text { very } \\
\text { Low }\end{array}$ & 0.141 & \\
\hline \multirow{6}{*}{ 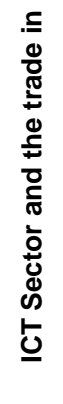 } & $\begin{array}{r}\text { Share of ICT value added in } \\
\text { business sector's value added }\end{array}$ & Medium & 0.425 & & Low & 0.285 & & $\begin{array}{l}\text { very } \\
\text { Low }\end{array}$ & 0.142 & \\
\hline & ICT cost & & & & & & & & & \\
\hline & Utilizing new business models & $\begin{array}{r}\text { very } \\
\text { High }\end{array}$ & 0.712 & & don't use & 0 & & don't use & 0 & \\
\hline & Utilizing new pricing models & & & & & & & & & \\
\hline & $\begin{array}{r}\text { Affordability of hardware and } \\
\text { software }\end{array}$ & Medium & 0.41 & & High & 0.548 & & High & 0.548 & \\
\hline & Cost savings in business process & High & 0.569 & & Low & 0.285 & & $\begin{array}{l}\text { very } \\
\text { Low }\end{array}$ & 0.143 & \\
\hline
\end{tabular}

Table-5: E-readiness values of three ICT companies based on deminesion-4: promotion \& facilitation 


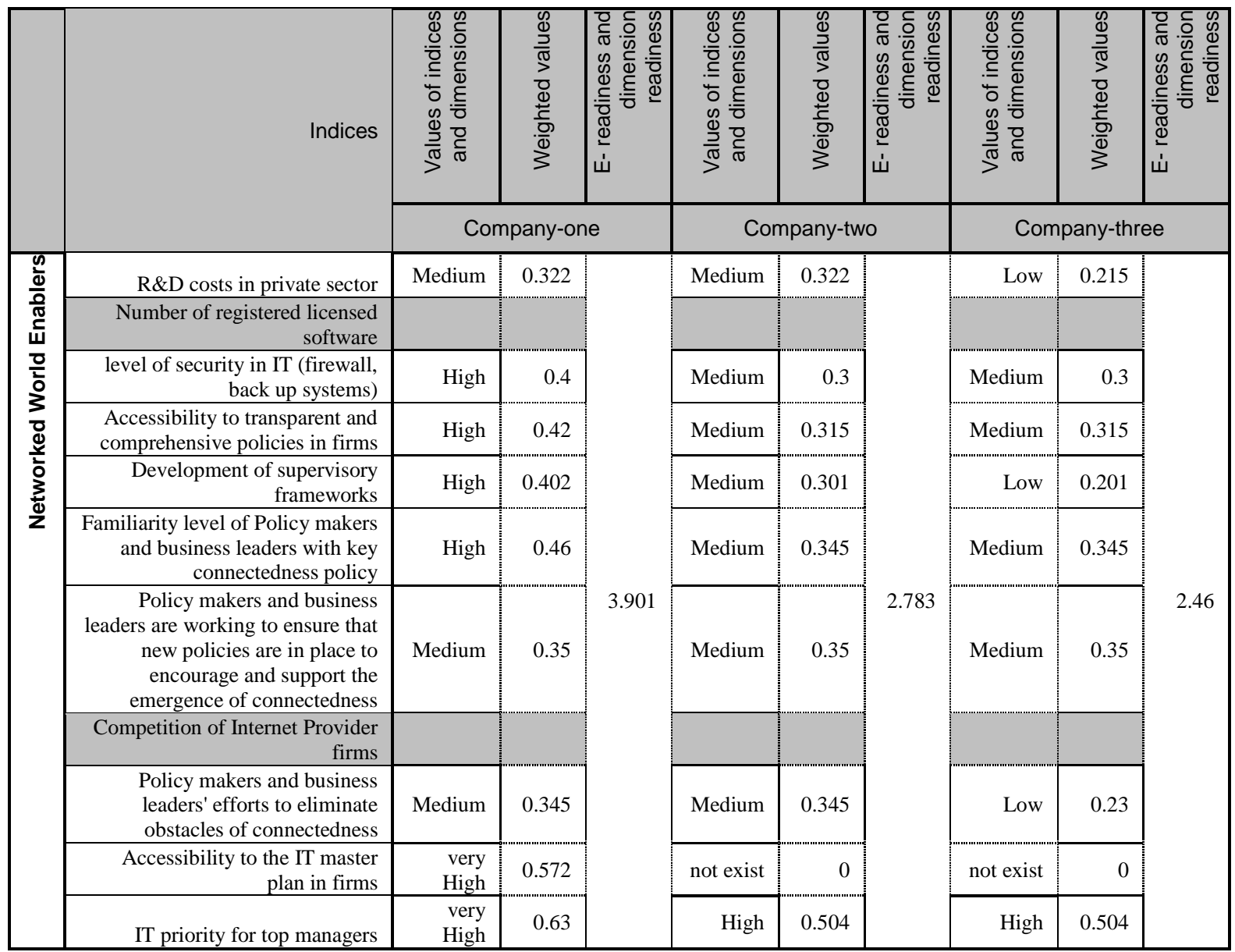

Table-6: E-readiness values of three ICT companies based on deminesion-5: Positioning for the digital economy 